\title{
Erratum: Baricitinib in patients with inadequate response or intolerance to conventional synthetic DMARDs: results from the RA-BUILD study
}

Dougados M, van der Heijde D, Chen Y-C, et al. Baricitinib in patients with inadequate response or intolerance to conventional synthetic DMARDs: results from the RA-BUILD study. Ann Rheum Dis 2017;76:88-95.

Page 91 states: Herpes zoster infections $(n=7)$ were seen in the baricitinib 2 and $4 \mathrm{mg}$ groups with similar frequency; none were visceral or disseminated. Herpes zoster distribution beyond the primary or adjacent dermatomes was seen in one patient (baricitinib $4 \mathrm{mg}$ ).

\section{(6) \\ OPEN ACCESS}

Open Access This is an Open Access article distributed in accordance with the Creative Commons Attribution Non Commercial (CC BY-NC 4.0) license, which permits others to distribute, remix, adapt, build upon this work noncommercially, and license their derivative works on different terms, provided the original work is properly cited and the use is non-commercial. See: http://creativecommons.org/licenses/by-nc/4.0/

(C) Article author(s) (or their employer(s) unless otherwise stated in the text of the article) 2017. All rights reserved. No commercial use is permitted unless otherwise expressly granted.

Ann Rheum Dis 2017;76:1634. doi:10.1136/annrheumdis-2016-210094corr1 